\title{
Women Exploitation: Violence against Women in India
}

\author{
Neha Sharma ${ }^{1}$ Sunita $^{1}$ *
}

\section{ABSTRACT}

Violence against women is very important and contemporary issue of discussion in India. In this regard, the policies of Indian government always have tried to overcome and solve the problem of violence against women by providing them valuable justice. But even after providing so many legislations and constitutional rights in favor of women by Indian government, still, women of India have faced many types of violence such as gang rape, spousal rape (marital rape) and sexual harassment especially. The present study is focused on the violence against women occurring in Indian society. The study reveals that very few women in India have approached to the help of police force in emergency situations, so that, there is a great need of conducting various awareness programs among women and Indian society about various preventive and remedial measures of violence against women. There must be to set up a women helpline team which serves as a quick redressal mechanism for protection of women against this mercy less crime.

Keywords: Women Exploitation, Rape and Sexual Harassment, Crime against Women.

"Yaa Devi Sarva Bhooteshu Matru Roopena Samsthita Namastasyai Namastasyai Namastasya Namo Namaha"

Any act of gender-based violence which may result into suffering physical, sexual, psychological (arbitrary deprivation of women liberty) exploitation or abuse, whether it is happening at either home, educational institution or another work places, comes under the major issue of violence against women. India is $7^{\text {th }}$ largest country by area and the second most populous with over 1.2 billion people, the most populous democracy over the world. The Indian economy is world's $10^{\text {th }}$ largest by nominal GDP (Gross Domestic Product). But in this India annual growth rate of crimes against women (2001-2011) is also 4.7\%. Total numbers of crimes against women are 2, 28,650. Topic of violence against women is not new for India. Violence against women is a universal and a serious problem for society that harms women's rights. Women tolerate many problems during lifetime since birth. Different types of women violence such as Domestic violence, Female infanticide and feticide, Dowry system etc. Rape and sexual harassment are two out of them serious crime. These are the two sides of the same coin. Number of cases of rape is increased continuously in India. In daily lives, a woman suffers many uneven

\footnotetext{
${ }^{1}$ M.phil. Dept. of Commerce, Indira Gandhi University, Meerpur (Rewari), Haryana *Corresponding Author

(c) 2015 I N Sharma, Sunita; licensee IJIP. This is an Open Access Research distributed under the terms of the Creative Commons Attribution License (http://creativecommons.org/licenses/by/2.0), which permits unrestricted use, distribution, and reproduction in any Medium, provided the original work is properly cited.
} 
things in buses, taxis, auto, workplace (office), especially at home. $40 \%$ of women experienced violence by age 15 year, 29\% of all women have experienced physical assault, 38\% of girls in years 10-12 have experienced unwanted sex. As per the data of $201296.32 \%$ rape cases committed by known person with women (friends, neighbors, relatives etc.) and only 3.68\% cases committed by strangers. So, the thing is clear that women are not safe even at their home. According to National Crime Bureau Records (NCBR) every sixty minutes, two women are raped in India. As per NCRB, in 2001 rape cases (sec. 376 IPC) were 16075 and in 2011 it is 24206, there is increase of 50.58\% moreover, molestation (sec. 354 IPC), in 200134124 cases were lodged whereas 42968 in 2011 (25.92\% increment).

\section{REVIEW OF LITERATURE}

Solidarity of the Nation Society (2009), reported that majority of women were married in the age of 16-20 years, most of the respondents were illiterate, women responded that their participation was nil in family decision making, all the decisions of family issues are taken by their husband, father-in law and mother-in-law. Most of the women had experienced physical violence such as beating, pushing, slapping and sexual abuse. UN Women (2011) reported that 10\% women tolerated sexual violence whereas $35.1 \%$ physical violence by their husband during life. Fimate and Devi (1998) found that in most of the rape cases, victims were acquainted with rapist. Suri and Sanjeeda (2013) collected data from 100 rape victims and found that majority of respondents were uneducated, unmarried (96\%) and from lower social background. Mostly victims were teenagers. Most of the Victims were from lower and middle social segment; these segments had no awareness about their rights. Kruthika (2013) found in their study that women respondents responded that they have tolerate sexual harassment (3.9\%) and experienced domestic violence due to drinking and gambling habit of husband. Madan (2014) analyzed in their research that females are not considered equal to the males. Even women literacy regarding their rights is not playing a prominent role to aware them. Sarkar et.al, analyzed with 90 rape victims that majority of victims were raped in their house (41\%) and rapist were known person. Majority of female victim's age were 11-20 years further most of the victims were Hindu. Kapoor and Dhingra (2013), analyzed many causes which trigger sexual assault and rape i.e. dominance nature of men over women, revenge, alcohol and drugs etc. view point of society that rape and sexual assault took place just because of wearing style of women and late night parties, friendly behavior of women with men.

\section{Statement of Problem}

Women exploitation is a serious problem and the question is that why an exploited women lives in society, cannot have any right to get justice even after introducing various laws in favor of Indian women. In our day to day life, we have seen and heard various news regarding gang rape, minor rape, kidnapping and then murder of girls. Turn on TV \& Radio; same news are telecasting there, record books of police stations are having the many cases of these heinous crimes. Sexual harassment is a form of sex discrimination. "Inappropriate behavior of a sexual nature, such as sexual advances or offensive remarks that occurs usually in a workplace, school 
or other institutional setting, especially by a person in authority with respect to a subordinate or a student” is also sexual offence. The rape may be in the form of date rape, gang rape, spousal rape (marital rape), rape of children, prison rape, payback rape (punishment or revenge rape), war rape, rape by deception (rapist acquires the victim's consent fraudulently), corrective rape, custodial rape (i.e. rape by police officer, hospital employee, and rape of children in orphanages).

\section{OBJECTIVES}

Following are the objectives of the present study:

1. To examine the issue of violence against women in India.

2. To analyze the rape and sexual harassment cases against women in India.

\section{RESEARCH METHODOLOGY}

The present study carried out from the secondary data. Collection of data on violence against women India has been carried out from various journals, newspapers, magazines and various reports of National Crime Records Bureau Report during the study period, 2007-2014.

\section{Issues of Women Exploitation in India}

There are so many several issues of women exploitation in India. In India, when a women is sexually harassed or exploited by someone and wants to get justice in favor of her then she is pressurized by her parents and society to not go for the help of police because the basic mentality of Indian society is that if any women go for police station to get valuable justice then it is a very big mistake and insult of her in society. That's why Indian women can't get proper and fair justice. The another issue is that the police force in India do not proper perform their duty in transparent manner (jack problem) for women welfare, so that, when a women is trying to get registered her case then her case is manipulated by corrupted police officers because some of the corrupted officers humiliate the right of exploited women in consideration of greed of getting money from criminal party. That's why women are abused by them and have not get any transparent justice and back out their steps towards her case. Recently, a teenager girl of XII standard committed suicide due to continuous harassment by three men in Ghaziabad in October, 2015 and a two and half year's minor girl in Delhi has been raped and then cruelly thrown to the park by two men in October 2015. This is real picture of modern India. The major issue of women exploitation in India is the awareness problem. The most if the Indian society is lack aware about how to get registered their complaint in police station and what is the procedural work after registering the case of sexual offence in police station, so that the Indian women are highly exploited in modern era of $21^{\text {st }}$ century.

\section{RESULTS AND DISCUSSION}

As per availability of National Crime Records Bureau data, very large number of rape and sexual offences had been occurred and registered during the study period, 2007-2014, which indicates the real picture of recent India against women exploitation. 
Table 1: Rape and Sexual Harassment cases in India: 2007-2014

\begin{tabular}{|l|l|l|l|l|l|l|l|}
\hline S.No. & Years & $\begin{array}{l}\text { Rape } \\
\text { cases } \\
\text { (Sec. 376) }\end{array}$ & $\begin{array}{l}\text { Percentage } \\
\text { (Rape cases) }\end{array}$ & Rank & $\begin{array}{l}\text { Sexual } \\
\text { harassment } \\
\text { cases }\end{array}$ & $\begin{array}{l}\text { Percentage } \\
\text { (sexual } \\
\text { (harassment) }\end{array}$ & Rank \\
\hline 1 & 2007 & 20737 & 10.10 & 8 & 10950 & 13.54 & 3 \\
\hline 2 & 2008 & 21467 & 10.45 & 6 & 12214 & 15.11 & 1 \\
\hline 3 & 2009 & 21397 & 10.42 & 7 & 11009 & 13.62 & 2 \\
\hline 4 & 2010 & 22172 & 10.80 & 5 & 9961 & 12.32 & 4 \\
\hline 5 & 2011 & 24206 & 11.79 & 4 & 8570 & 10.60 & 8 \\
\hline 6 & 2012 & 24923 & 12.14 & 3 & 9173 & 11.35 & 7 \\
\hline 7 & 2013 & 33707 & 16.41 & 2 & 9230 & 11.42 & 6 \\
\hline 8 & 2014 & 36735 & 17.89 & 1 & 9735 & 12.04 & 5 \\
\hline $\mathbf{9}$ & Total & $\mathbf{2 , 0 5 , 3 4 4}$ & $\mathbf{1 0 0}$ & & $\mathbf{8 0 , 8 4 2}$ & $\mathbf{1 0 0}$ & \\
\hline $\mathbf{1 0}$ & Min & $\mathbf{2 0 7 3 7}$ & $\mathbf{1 0 . 1 0}$ & & $\mathbf{8 5 7 0}$ & $\mathbf{1 0 . 6 0}$ & \\
\hline $\mathbf{1 1}$ & Max & $\mathbf{3 6 7 3 5}$ & $\mathbf{1 7 . 8 9}$ & & $\mathbf{1 2 2 1 4}$ & $\mathbf{1 5 . 1 1}$ & \\
\hline
\end{tabular}

Source: National Crime Records Bureau Report (2007-2014), Ministry of Home Affairs

Table 1 shows the consolidated data of rape (sec. 376) and sexual harassment cases in India from the period of 2007 to 2014. As shown in above table, numbers of rape cases had been continuously increased (15998) from the year 2007 to 2014; therefore it is a very shameful situation for India. The maximum number of rape cases (17.89 per-cent) were registered during the year 2014 followed by 16.41 per-cent during the year 2013, 12.14 per-cent during the year 2012, 11.79 per-cent during the year 2011, 10.80 per-cent during the year 2010, 10.45 per-cent during the year 2008, 10.42 per-cent during the year 2009 and very least as 10.10 per-cent during the year 2007 respectively during the study period 2007-2014. Additionally, the least number of sexual harassment cases (10.60 per-cent) were registered during the year 2011 followed by 11.35 during the year 2012, 11.42 per-cent during the year 2013, 12.04 per-cent during the year 2014, 12.32 per-cent during the year 2010, 13.54 per-cent during the year 2007, 13.62 per-cent during the year 2009 and maximum as 15.11 during the year 2008 respectively during the study period 2007-2014. So that, the number of sexual harassment cases registered in India had been decreased (2479) from the period of 2008 to 2014; therefore it is an improved situation for India. 
Table 2: State wise incidence of IPC crimes under sexual offences during the year 2014

\begin{tabular}{|c|c|c|c|c|c|c|c|}
\hline S.No. & States & $\begin{array}{l}\text { Rape } \\
\text { cases }\end{array}$ & $\begin{array}{l}\text { Attempt } \\
\text { to } \\
\text { Commit } \\
\text { rape }\end{array}$ & $\begin{array}{l}\text { Assault on } \\
\text { women with } \\
\text { Intent to } \\
\text { outrage her } \\
\text { modesty }\end{array}$ & $\begin{array}{l}\text { Insult to the } \\
\text { modesty of } \\
\text { women } \\
\text { (sexual } \\
\text { harassment) }\end{array}$ & $\begin{array}{l}\text { Total } \\
\text { (sexual } \\
\text { offences) }\end{array}$ & $\begin{array}{l}\text { Rank } \\
\text { (Total } \\
\text { sexual } \\
\text { offences) }\end{array}$ \\
\hline 1 & Andhra Pradesh & 961 & 165 & 4547 & 2649 & 8322 & 6 \\
\hline 2 & Arunachal Pradesh & 83 & 10 & 121 & 3 & 217 & 27 \\
\hline 3 & Assam & 1980 & 227 & 3099 & 1 & 5307 & 12 \\
\hline 4 & Bihar & 1127 & 484 & 572 & 69 & 2252 & 17 \\
\hline 5 & Chhattisgarh & 1436 & 21 & 2122 & 79 & 3658 & 13 \\
\hline 6 & Goa & 95 & 2 & 202 & 57 & 356 & 24 \\
\hline 7 & Gujarat & 841 & 6 & 1352 & 173 & 2372 & 15 \\
\hline 8 & Haryana & 1174 & 136 & 1688 & 102 & 3100 & 14 \\
\hline 9 & Himachal & 283 & 5 & 538 & 60 & 886 & 21 \\
\hline 10 & Jammu\& Kashmir & 331 & 20 & 1421 & 237 & 2009 & 18 \\
\hline 11 & Jharkhand & 1050 & 208 & 440 & 18 & 1716 & 20 \\
\hline 12 & Karnataka & 1324 & 22 & 5263 & 170 & 6779 & 9 \\
\hline 13 & Kerala & 1347 & 36 & 4367 & 257 & 6007 & 10 \\
\hline 14 & Madhya Pradesh & 5076 & 56 & 9609 & 429 & 15170 & 1 \\
\hline 15 & Maharashtra & 3438 & 15 & 10001 & 1575 & 15029 & 2 \\
\hline 16 & Manipur & 75 & 1 & 98 & 0 & 174 & 28 \\
\hline 17 & Meghalaya & 118 & 26 & 105 & 54 & 303 & 25 \\
\hline 18 & Mizoram & 120 & 1 & 97 & 29 & 247 & 26 \\
\hline 19 & Nagaland & 30 & 3 & 16 & 1 & 50 & 32 \\
\hline 20 & Odisha & 1978 & 33 & 5543 & 379 & 7933 & 7 \\
\hline 21 & Punjab & 981 & 154 & 1113 & 35 & 2283 & 16 \\
\hline 22 & Rajasthan & 3759 & 373 & 5999 & 18 & 10149 & 4 \\
\hline 23 & Sikkim & 47 & 9 & 34 & 3 & 93 & 30 \\
\hline 24 & Tamil Nadu & 455 & 16 & 1102 & 229 & 1802 & 19 \\
\hline 25 & Telangana & 979 & 73 & 3188 & 1142 & 5382 & 11 \\
\hline 26 & Tripura & 239 & 35 & 492 & 11 & 777 & 22 \\
\hline 27 & Uttar Pradesh & 3467 & 324 & 8605 & 29 & 12425 & 3 \\
\hline 28 & Uttrakhand & 270 & 41 & 343 & 4 & 658 & 23 \\
\hline 29 & West Bengal & 1466 & 1656 & 5670 & 543 & 9335 & 5 \\
\hline 30 & A \& N Island & 32 & 0 & 41 & 5 & 78 & 31 \\
\hline 31 & Chandigarh & 59 & 6 & 87 & 2 & 154 & 29 \\
\hline 32 & D \& N Haveli & 5 & 0 & 2 & 1 & 8 & 33 \\
\hline 33 & Daman \& Diu & 2 & 0 & 3 & 0 & 5 & 34 \\
\hline 34 & Delhi & 2096 & 70 & 4322 & 1361 & 7849 & 8 \\
\hline 35 & Lakshadweep & 1 & 0 & 1 & 2 & 4 & 35 \\
\hline 36 & Puduchery & 10 & 0 & 32 & 8 & 50 & 32 \\
\hline 37 & Total (All India) & 36,735 & 4,234 & 82,235 & 9,735 & $1,32,939$ & \\
\hline
\end{tabular}

Source: National Crime Records Bureau Report (2014), Ministry of Home Affairs 
Table 2 exhibits the state wise incidence of IPC crimes under sexual offences during the year 2014. As per National Crime Records Bureau Report (2014), the maximum cases of sexual offences has been registered in Madhya Pradesh (15170) during the year 2014 followed by Maharashtra (15029), Uttar Pradesh (12425), Rajasthan (10149), West Bengal (9335), Andhra Pradesh (8322), Odisha (7933), Delhi (7849), Karnataka (6779), Kerala (6007), Telangana (5382), Assam (5307), Chhattisgarh (3658), Haryana (3100), Gujarat (2372), Punjab (2283), Bihar (2252), Jammu\& Kashmir (2009), Tamil Nadu (1802), Jharkhand (1716), Himachal (886), Tripura (777), Uttrakhand (658), Goa (356), Meghalaya (303), Mizoram (247), Arunachal Pradesh (217), Manipur (174), Chandigarh (154), Sikkim (93), A \& N Island (78), Puduchery (50), Nagaland (50), D \& N Haveli (8), Daman \& Diu (5) and Lakshadweep (4) respectively.

\section{CONCLUSION}

The study found that even after various new legislations and amendments made in existing laws and constitution, rape cases had been continuously increased in India during the study period 2007-2014; so that it indicates a very poorest situation for safety of Indian women. But on the other hand, after introducing the various new amendments in present constitution, the cases of sexual harassment are least seen from the period of 2008 to 2014; so that it is an improved version of law in favor of women rights. The present study also reveals that the maximum sexual offences cases (rape and sexual harassment) in India, has highly been registered in Madhya Pradesh and very lowest in Lakshadweep during the year 2014. In the modern era of globalization, the Indian women have failed to access transparent justice till now. So, for proper solution of this major problem, state government of Haryana has initiated steps towards to set up the separate women police stations in each district of Haryana for women in order to provide valuable justice to exploited ladies and punished the mercy less men.

\section{SUGGESTIONS TO OVERCOME THIS PROBLEM}

- There must be self defense training mechanism established at District level \& educational institutions along with academics and should also motivate girls to participate into such training programs, so that they can fight against crime her selves and would become confident too.

- So many girls are there, who don't lodge FIR against the crime that have happened to them due to the fear of society that they would be accused for all what has happened with them, so all we need to create such healthy environment for victims that they are free to tell society and the police what mishappening they have faced. Our step will help the victims to raise voice against this crime and to get justice.

- No doubt, there are many laws for these crimes but laws and order needs to be more firm and rude regarding the culprits, special provisions regarding women safety should be passed in parliament.

- Girl education and various awareness programs needs to be promoted because majority of victims are found illiterate/uneducated (Suri \& Sanjeeda 2013). So, it is most to develop a firm education system for women.

- Police force has to be more active to play vital role to overcome this problem. 
- "Unity is Strength" so please not to leave victim alone, in fact be with her to get justice. We all have to break the dirty politics of our politicians over this matter and have to establish a central cell together to fight against this crime.

- There must be a great need of separate police stations have to be established for women in each and every states of India at district level and the criminals of sexual offences must to get death punishment.

- The most important thing is the parental support of sexually harassed girls provides a valuable strength in this fight. If an each and every parent of an exploited girl takes the strong step against such criminals and to support their child's dignity through law then their parental support must be overcome such problem.

- Indian women constitute the equal rights as like as men, but this equality is only limited to books not in practical life. Hence, it is very essential to aware about their fundamental rights so that they can protect themselves from this violence and fight against sex discrimination.

- There should authenticated NGO's be established for help of exploited women so that they can easily access them to gets timely \& fair justice

\section{REFERENCES}

Delhi Police (The Hindu news Staff Reporter NEW DELHI, January 19, 2013)

Fimate, L. \& Devi, M. (1998), “An analytical study of rape in Manipur”, International Journal of Medical Toxicology and Legal Medicine, Vol. 1, pp. 1-2.

Kiruthika (2013), "A statistical study on nature and extent of violence against women in Puducherry”, IOSR Journal of Humanities and Social Science (IOSR-JHSS), Vol. 18 (1), pp. 01-05.

Madan, Sonu (2014), "Nature \& extent of violence against women in India”, Vinayek Global Research Review, Vol. 1 (1 \& 2), pp.23-31.

NDTV.com

S.C Sarkar, S. Lalwani, R. Rantji, D.N. Bhardwaj \& T.D. Dogra, “A study on victims of sexual offences in South Delhi”, (ssrn.com).

Socio-Economic \& Educational Backward of Victims of Domestic Violence in India, 2009, Solidarity of the Nation Society.

Suri and Sanjeeda (2013), "An analytical study of rape in Delhi”, International Journal of Education and Psychological Research (IJEPR), Vol. 2 (3), pp. 60-68.

Varoon Kapoor, Kanika Dhingra (2013), "Sexual harassment against women in India”, OIDA International Journal of Sustainable Development, pp. 85-92.

\section{Webs}

www.ncrb.gov.in

www.wikipedia.org 